\title{
Analysis of Teachers Perception of Their Public Image and It Influence on Students Performance in Physics: A Key to Improving the Quality of Education in Nigeria
}

\author{
Mallo Yohanna lliya \\ Akila Simdet \\ Physics Department \\ Federal College of Education, Pankshin-Nigeria
}

\section{Doi:10.5901/mjss.2013.v4n12p113}

\section{Abstract}

The study examined teachers' perception of their public image and its influence on students' performance in physics in Pankshin Local Government Area of Plateau State. A survey research designed was employed for the study; the study population was all secondary school in Pankshin L.G.A of Plateau State. 100 teachers and students were used as sample using simple random sampling techniques. The study was guided by three research hypothesis. A 16 items questionnaire was the instrument used to collected data from the sample and students' performance was also collected. The instrument was validated by experts and a reliability coefficient of 0.90 was established using test-retest method. Pearson Product Correlation Coefficient was used to test the research hypothesis. From the findings, Government and students attitude towards the teacher contributes to teachers public image in turn have a negative effect on students performance. The paper recommended that Government/employers of labour should show regards for teacher by meeting their demands to encourage them in their job. Also parents, teachers and government should put heads together to ensure that student attitudes towards teachers change positively to achieve improved performance.

Keywords: teachers, image, perception, students' performance, physics.

\section{Introduction}

Academic success is a function of the teacher who is the key, the students who are the focus, the environment and the parents who have a great role to play. The role of the teacher in any learning environment is to ensure that the learners acquire the knowledge expected of them. In both formal and informal education, the teacher is at the fore front of curriculum implementation hence he is considered capable of performing the job. An ideal teacher provides instruction in such a way that will lead to high level of student achievement interms of students outcome such as learning gains and work readiness.

Students on their own part, have a task of listening and paying attention to the teacher, carrying activities and responsibilities assign to them by the teacher. Cogan (1975) stressed that students who share and amplify their elders disparagement of the teacher will tend to learn less, forget faster, transfer and apply their learning less readily than if these learning had been gained in pervading atmosphere of high esteem for teacher. From the forgoing, it is imperative that the teachers image is a significant factor in students, learning. The way the students perceive the teacher determines their attitude to the subject and in turn their interest and readiness to learn.

Parents have the responsibility of supporting the teacher effort by providing the necessary things required of them from the students. An ideal learning environment therefore requires a smooth relationship between teacher, student, parents and the society at large. Emengu (2005) affirmed that poor conditions of 
services, heavy work load, remuneration, low social and public image ingratitude by other officer and continued ingratitude shown to teacher by parents and public in general have frustrated many teachers and have forced them to develop low morale.

One does not look to closely at teaching to know that one of the causes of poor academic achievement of students is low regard for to teachers. What most affect the students performance is the quality of the teacher in the classroom and also the respect he receives from the society as a whole.

To improve on the quality of education, there is need to put heads together with the teacher for affection learning to be achieved. Geo, Belly and Kittle's (2008) said effective teachers collaborate with other teachers, administrator, parents and educational professionals to ensure students success particularly the success of the students with special needs and those at high a risk for failure.

The teacher being a helper, a mentor, a planner, a mornitor, and evaluator, a developer and a collaborator of educational system needs to be motivated by the society through cooperating with him, appreciating his effort, protecting his, image, financing his programme and above all putting heads together with the teacher to ensure success in the teaching learning program.

\section{Teacher's Public Image. The State of the Art}

The recent industrial strike action embark upon by teachers of various institutions of learning is an evidence of an existing problem between the teachers and employers of labour/government. The negligence of government to the teacher's demand have demonstrated high level of disregard of teachers in the society. For instance Academic Staff Union of Universities (ASUU) on going strike action which started on the first of July 2013. (1-7-2013) to date for lack of implementation of the agreement reached between them and the government since 2009. Okoroafor (2006) noted that the teacher can be said to be all and end all of all situations but ironically he is not instead he is in Nigeria today a laughing stock of all professions. Olabisi (2005) observed that the public population generally regard teaching as an undesirable occupation in Nigeria. the resultant effect is that, the self image of the teacher appears touch of apology. The findings of Oladije (2009) and Okeye (2010) revealed that the perception a student has on the teacher is the same as that he has on the subject.

\section{Statement of the Problem}

In spite of the importance of the teacher as the engine that pulls educational system along to the land of knowledge. Evidence of teachers disregard in the society is pointed by Emengu (2005) and Olabisi (2005). Teachers being human are sometimes conscious of their rating in the society and their feelings may become attitude to work on their students. This in turn affect students performance as stressed by Ada (2002) and Okeye (2010). It therefore becomes necessary to monitor what the teacher thinks about his/her job and his/her students in the light of confusion from the society about the image of the teachers.

The problem of this study therefore, is what teachers perceive their public image to influence their duty performance with regard to the academic achievement of their students.

\section{Purpose of the Study}

The purpose of the study is to examine the teacher's perception of their public image and its influence on the academic achievement of physics students, the research work looks at the following objectives.

1. To find out the perception of physics teachers in Pankshin Local Government of their public image.

2. To find out the perception of physics teachers in Pankshin Local Government whether their public image has impact on the academic achievement of their students.

3. To find out the causes of the teachers public image in Pankshin Local Government. 
4. To determine the strategies for improving teachers public image.

\section{Hypothesis}

1. There is no significant relationship between parents perception of the teacher and students performance in physics.

2. There is no significant relationship between government/employer's attitudes towards teachers and students performance in physics.

3. There is no significant relationship between student's attitude towards teachers and their performance in physics.

\section{Methodology}

The researcher adopted a descriptive survey research in carrying out this research. The population consists of all secondary schools in Pankshin local government area of Plateau Stat. The size of the population was 180 science teachers and 983 students. Random sampling techniques was used to select 10 schools (100 teachers and 100 students).A researcher made instrument four point liked scale of Strongly Agree (SA), Agree (A), Disagree (D) and Strongly Disagree (SD) questionnaire which covered all information regard the topic was used. The content validity of the instrument was determined by an instruments and the reliability value of 0.94 was obtained using test-retest method and Pearson product moment correlation coefficients. The copies of the questionnaire were administered to the sample workers an interval of 10 minutes was given to respond to the items as stipulated in the questionnaire after which the performance of the students was also collected.

\section{Method of Data Analysis}

The data collected were analyzed using pearson product moment correlation ( $r$ ) and t-test ratio. All hypotheses were tested at 0.05 level of significant $(\mathrm{x})$.

\section{Testing the Research Hypothesis}

The analysis of data presented below follow the sequence in which the null hypothesis were initially stated

\subsection{Hypothesis One $(\mathrm{HO})$}

There is no significance relationship between parents perception of the teacher and students performance.

Table 1: Showing the analysis of the relationship between parents perception and students performance using the Pearson product moment method.

\begin{tabular}{|c|c|c|c|c|c|}
\hline Of $\mathrm{r}$ & $\mathrm{T}_{\text {cal }}$ & $\mathrm{T}_{\text {crit }}$ & Degree of freedom & Level of significance & Decision \\
\hline & 6.54 & 2.132 & 4 & 0.05 & Rejected $\mathrm{Ho}$ \\
\hline
\end{tabular}

In table 1 the calculated value of $t$ is 6.54 and its greater than the critical value of $t 2.132$ at 0.05 level of significance. This implies that the parents perception of teacher affect students performance. Which means null hypothesis is accepted since $t_{\text {cal }}>t_{\text {crit. }}$. 


\subsection{Hypothesis Two $(\mathrm{HO})$}

There is no significance relationship between government/employers attitudes toward teachers and student performance.

Table 2: Showing the analysis of the relationship between government/employers attitude towards teachers and students performance using the Pearson moment method.

\begin{tabular}{|c|c|c|c|l|}
\hline$T_{\text {cal }}$ & $T_{\text {crit }}$ & Degree of freedom & Level of significance & Decision \\
\hline 2.3449 & 2.015 & 5 & 0.05 & Rejected \\
\hline
\end{tabular}

In table 2 calculated value of $t$ is 2.345 and its greater than critical of $t=2.015$ at 0.05 level of significance which implies that Government/employers attitude and the teacher affect students performance. Which implies that hypothesis is rejected and alternative hypothesis is accepted the $t_{c a l}>t_{\text {crit. }}$.

\subsection{Hypothesis Three}

There is no significance relationship between students attitude towards teachers and their performances.

Table 3: Showing analysis of students attitudes towards teachers using Pearson product moment correlation coefficients method.

\begin{tabular}{|c|c|c|c|c|c|}
\hline Value of $r$ & $T_{\text {cal }}$ & $T_{\text {crit }}$ & Degree of freedom & Level of significance & Decision \\
\hline 1.4034 & 2.469 & 2.132 & 4 & 0.05 & Reject Ho \\
\hline
\end{tabular}

In table 3 the calculated value of $t$ is 2.469 and its greater than the critical value of t, 2.132 at 0.05 level of significance which implies that students attitude towards their teachers has great influence on their performance. Which means null hypothesis is rejected since $t$ cal $>t$ crit.

\section{Conclusion}

On the basis of this research finding the following conclusion were drawn.

1. Parents perception of teachers affect student performance.

2. Government/employers attitude towards the teachers affect students performance.

3. Students attitude towards their teacher has great influence on their performance.

\section{Recommendations}

Based on the results of this study the following recommendations were made:

1. Government/employers should show regards for the teachers by meeting their demands to encouraged them in their job.

2. Both parents, teachers and government/employers of labour should put heads together to ensure that students attitude towards teachers/studies change positively as follows;

- Parents should play their advisory role as well as make available what is required of the learners for their study.

- Teachers should create good teachers students relationship by way of apply teaching method that will captivate students interest towards learning. 
- Government on their own part makes provision for conducive learning environment for both teachers and students.

\section{References}

Cogan, R.B. (1975). The conditions of harming. New York Rinheard and Wiston.

Emenogu, B.C. (2005). Perspective in Teacher Effectiveness. Nigeria: Oreint Publishers, 197.

Geo, L. Belly, C. \& Little, O. (2008). Approaches to evaluation teachers for teacher quality: retrieved September, 8, 2010 from http://.www.tqsource.org/strategies.

Okeye, E.O. (2010). The Nigerian school system: Unwin Limited.

Okoroafor, N. (2006). Plight of Teachers: Daily times August, 17:3

Olabisi, K., (2005). "Payment of Teacher Salary Arraras". The Guardian, January 5:1.

Olajide, J.B. (2009). A survey of student's perception of the Biology in Ibadan Secondary School. M. Ed. Thesis (unpublished) University of Ibadan. 
